\title{
Effect of bacterial additives on the performance of septic tanks for wastewater treatment in the Upper Egypt rural area
}

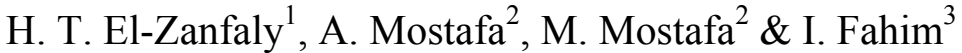 \\ ${ }^{1}$ National Research Center, Water Pollution Control Department, Egypt \\ ${ }^{2}$ National Institute for Housing and Buildings, Egypt \\ ${ }^{3}$ Sanitary Waste Company, Egypt
}

\begin{abstract}
A mixture of five selected, adapted, enzyme active producer bacterial species has been used as an additive to septic tanks in order to test its ability to increase treatment efficiency.

Regarding the septic tanks receiving waste with medium load, the maximum removal was achieved at day thirty and showed ranges for removal \% reaching 91.3-94.4, 93-95.8, 90-91.7, 75-87, and 99.95-99.99 for COD, BOD ${ }_{5}$, TSS, oil and grease and total coliforms, respectively. Septic tanks without bacterial additives were able to show removal \% ranged as 79.3-88.5, 80-85.5, 75.1-83, 28-41.7 and 98.5-99.85 for the same parameters. Septic tanks that receiving influent with high load of pollutants, the maximum removal was achieved during the period of day 36-42 after addition of bacteria. The removal percentages for $\mathrm{COD}, \mathrm{BOD}_{5}$, TSS, oil and grease and total coliform were ranged as 93.8-97.2, 94.5-97.0, 94.0-97.9; 64.0-93.8; 99.81-99.99, respectively. Septic tanks without bacterial additives showed percentages of removal ranged as: 64.7-87.2, 73.4 89.6, 56.7-86.9, 34.6-45, and 92.8-99.28 for COD, $\mathrm{BOD}_{5}$, TSS, oil and grease and total coliforms, respectively.

Keywords: wastewater treatment, Egyptian rural area, septic tanks, bacterial additives.
\end{abstract}

\section{Introduction}

Septic tanks/soil absorption systems are an option to consider wherever a centralized treatment system is not available. It has been the most popular on-site 
method [1]. The septic tank is an underground, watertight vessel installed to receive wastewater from the home. It is designed to allow the solids to settle out and separate from the liquid, to allow for limited digestion of organic matter, and to store the solids while the clarified liquid is passed on for further biological, physical and chemical reactions through the subsurface wastewater infiltrations system. Collected solids undergo some decay by anaerobic digestion in the tank bottom and depending on the activity of natural microorganisms that exist in the waste with minimal human intervention. Scum and grease float to the surface and the baffles keep it out of the soil absorption system. If an excessive amount of sludge is allowed to collect in the bottom of the septic tank, wastewater will not spend a sufficient time in the tank before flowing into the soil. Depending on the retention time of liquids in the septic tank, further biological treatment is expected from the natural microorganism existed.

Clarified septic tank effluent exits the septic tank and enters the soil absorption system where a biological biomat forms, contributing to even distribution of the waste into the soil [2]. The character of wastewater flowing into the soil absorption area is a critical variable for proper functioning of septic system. Soil absorption systems work most effectively when the influent does not contain significant levels of settleable solids, greases and fats. To avoid infiltration soil clogging by grease and scum, outlet baffles are suggested. Also, the use of two-compartment tanks recommended over single-compartment design. Absorption beds and trenches are the most common design options for soil absorption systems [1].

Since digestion of wastes in septic tanks is performed biologically, it is a temperature dependent process and colder temperature as well as the addition of toxic substances (as detergents, bleaching agents, acids, solvents, etc.) which may hinder the effective biological breakdown of wastes in septic tanks [3, 4] and cause septic tank upset. In addition, other cases such as when someone in the home is on chemotherapy for an extended period of time and the unused septic tanks for long period or the high loads of the hard biodegradable materials, may destroy or stress the biological activity in the septic tank. Under all these conditions, it is possible to suggest the addition of biological additives in the form of enzymes or microorganisms to help speed the re-establishment of biological activities.

Failure of systems to adequately treat wastewater may be related to inadequate site, inappropriate installation, or neglectful operation. Hydraulic overloading has been identified as a major cause of system failure [5].

Septic systems can act as sources of nitrogen, phosphorus, organic matter, and microbial pathogens, which can have potentially serious environmental and health impacts [6]. Since septic wastewater contains various nitrogen compounds Brown, installation of septic systems in areas that are densely developed can, in combination with other factors, result in the introduction of nitrogen contaminants into groundwater. Groundwater impacts can occur even when soil conditions are favorable because the unsaturated aerobic treatment zone located beneath the drain-field promotes conversion of wastewater-borne nitrogen to nitrates. If nitrate contamination of groundwater is a concern in the rejoin, 
control methods or denitrifying technologies may be required for safe operation of a septic system. Conventional septic systems are designed to operate indefinitely if properly maintained. However, because most household systems are not well maintained, the functioning life of septic systems is typically 20 years or less [8].

\section{Materials and methods}

\subsection{Septic tanks}

Septic tanks had been modified by some organizations as on-site, simple and low cost wastewater treatment system in a group of villages in Upper Egypt. The modified septic tank, as shown in Fig. 1, consists of the same main components of the traditional one and represented by:

\section{a-entrance chamber b-sedimentation space c-distribution chamber d-outlet chamber}

There are anaerobic filter contained two layers of gravel. The bottom layer contained gravel (40-60 $\mathrm{mm}$ in diameter) of two third of the depth. The top layer contained gravel (20-40 $\mathrm{mm}$ in diameter). According to the design criteria, the retention time, is ranged as 1-3 days according to the tank type.
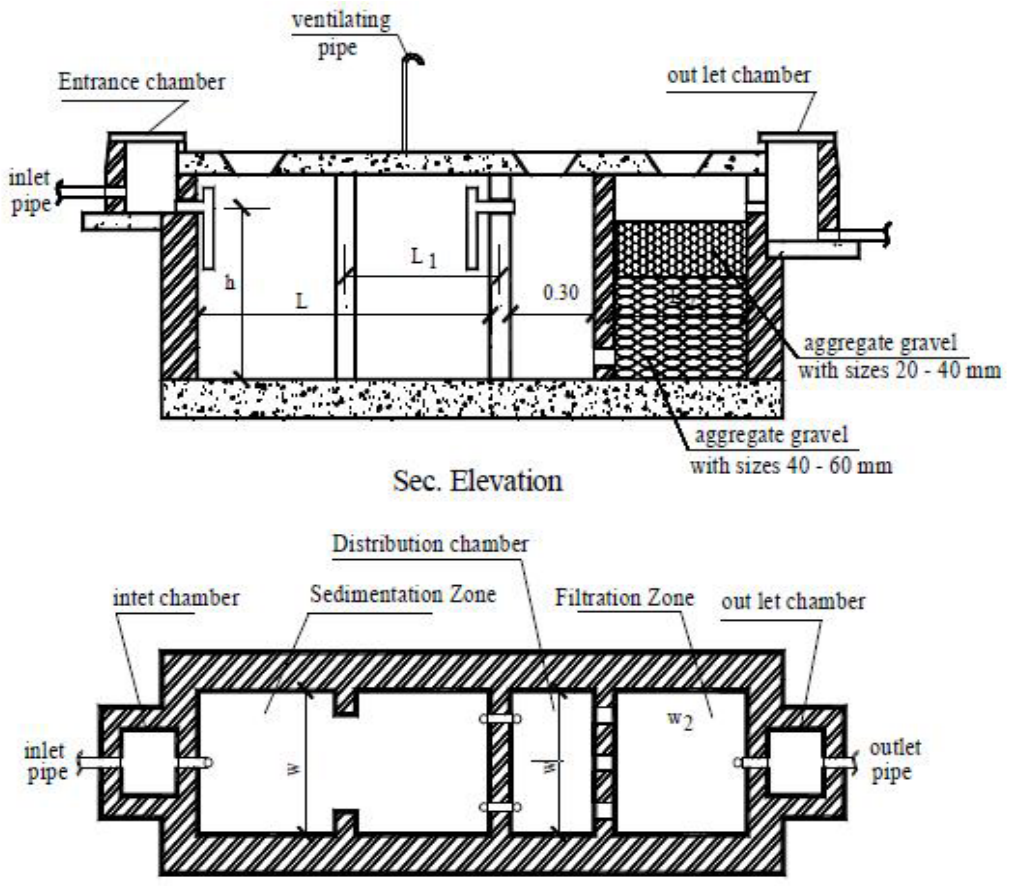

Sec. Plan

Figure 1: Typical modified septic tank. 
The experimental work was executed on two types of modified septic tanks. The $1^{\text {st }}$ type which receiving waste with medium organic load and serving 10 persons. The sedimentation chamber has the capacity of $2.4 \mathrm{~m}^{3}(\mathrm{~L}=2 \mathrm{~m}, \mathrm{~W}=1 \mathrm{~m}$ and $\mathrm{D}=1.2 \mathrm{~m}$ ), with retention time of 3 days. There was only one filter chamber with dimensions as, $\mathrm{L} 2=1 \mathrm{~m}, \mathrm{~W}=1 \mathrm{~m}$ and $\mathrm{D}=1 \mathrm{~m}$. The $2^{\text {nd }}$ type of septic tanks receiving wastes with high organic load and serving 200 persons (about 40 families). The sedimentation chamber with a capacity of $35.5 \mathrm{~m}^{3}$, and has dimensions as $\mathrm{L}=13 \mathrm{~m}, \mathrm{~W}=1.7 \mathrm{~m}$, and $\mathrm{D}=1.8 \mathrm{~m}$., with 2.2 days as retention time. There are two filter chambers each with dimensions of $\mathrm{L}=1.5 \mathrm{~m}$, $\mathrm{W}=1.7 \mathrm{~m}$ and $\mathrm{D}=1.2 \mathrm{~m}$. The bacterial additives were added to the wastewater inside the distribution chamber and before the gravel filter as a ratio of the quantity of the wastewater found in the sedimentation chamber.

\subsection{Bacterial cultures}

From sewage samples collected from septic tanks, 800 bacterial isolates were isolated, purified by streaking on tryptic soy agar medium and microscopically examined to ensure its purity. All the isolates were assayed for their enzymatic activity using different substrates and focusing on: protease, amylase, lipase, esterase, cellulase, xylanase and urease production. Two hundred and forty isolates were selected according to their high enzyme production activity and only 158 of them that were able to show stability in activity through twenty times of sub-culturing. Adaptation program was carried out on those 158 isolates through testing their ability to produce the mentioned enzymes at different temperature and $\mathrm{pH}$ values. Only 78 isolates that was able to show the ability to produce enzymes at wide range of temperature $\left(10-55^{\circ} \mathrm{C}\right)$ and $\mathrm{pH}$ values (4-10). Stability of the characters was tested by sequential culturing program using media containing sewage and finally only 23 isolates that could pass the screening tests. The Analytical Profile Index (API) identification system was followed and showed that the last 23 isolates could be grouped as belonging to 5 bacillus species. One strain of each species was selected, cultured on tryptic soy agar slants and kept in the refrigerator as stock culture to be used in the present study.

Two days before the experiment, the five strains were inoculated in nutrient broth and incubated at $37^{\circ} \mathrm{C}$ for $24 \mathrm{hr}$. The cultured strains were centrifuged at $4500 \mathrm{rpm}$ for $10 \mathrm{~min}$ and the sediment from every 1 liter culture was collected separately in sterile bottle and kept in the refrigerator. The sediments were transported to the site of the experiment in icebox. Every septic tanks gravel filters were seeded with the culture sediments (the sediment resulted from 1 liter of culture $/ \mathrm{m}^{3}$ of tank capacity).

\subsection{Sampling}

Samples from the effluent from the septic tank under study before and after inoculation the mixture bacterial strains were collected in sterile glass bottles and transported in icebox to the laboratory for bacteriological and chemical examinations. The parameters were determined according to the Standard 
Methods for the Examination of Water and Wastewater APHA [9], and included: total coliforms MPN/100, biochemical oxygen demand $\left(\mathrm{BOD}_{5}\right)$, chemical oxygen demand (COD), total suspended solids (TSS) and oil and grease.

\section{Results and discussion}

The application of bacteria for sewage treatment in septic tanks should ensure that it was conducted close to the recommendations prescribed by the U.S. Environmental Protection Agency $[1,8,10]$ for minimizing the environmental and/or user risk. U.S. EPA standards ensure that the number of microorganisms emitted from the site where microorganisms are used is minimized. It does not specify specific limits for the emitted microorganisms. EPA specified that the introduced genetic material, in case of genetic engineered stains, must be limited in size to reduce the risk of introduction uncharacterized genetic material. In the present study, the used strains were selected from the natural habitat which have high rate of enzymatic activity as well as it can grew at wide range of $\mathrm{pH}$ and temperature and not genetically engineered strains.

Although direct monitoring data are unavailable, worst case do not suggest high levels of the public exposure resulting from the application of these bacteria in well designed and maintained septic tanks. However, human exposure via dermal and ingestion routes as well as release to the environment may occur if the effluent from the treated septic tanks is discharged on an open area or directly on surface water.

In the present study, the used strains were isolated from sewage and exist as common organisms in soil and ubiquitous nature. They are neither nonpathogenic nor toxigenic $[11,12]$. For example, when B. licheniformis enter the human digestive system, it is not able to colonize to any large degree. However, if challenged by large numbers of this micro-organism, it may cause limited gastroentertities for only the compromised individuals [12]. Outside the gastrointestinal tract, it would likely be a temporary inhabitant of skin [13]. It is widely known as a contaminant of food, but not thought to be a causal agent for food poisoning [14]. There was no mention of any plant pathogenic activity [13].

The base considered in strains selection was to cover the various conditions at which the degradation of pollutants may occur (aerobically or anaerobically, and wide ranges of $\mathrm{pH}$ and temperature). The selected species of bacteria through their enzymatic activity can breakdown the different pollutants that usually occur in sewage such as carbohydrates, proteins, cellulose, urea, oil and grease (Table 1).

Three septic tanks located in villages namely Gragoos; Quina Governorate, El-Mahameid; Aswan Governorate, and Bany Sanad; Asuot Governorate were selected on the base that they receive wastewater influent with medium load of organics (COD 560-640 $\mathrm{mg} \mathrm{O}_{2} / 1$ and BOD 350-400 $\mathrm{mg} \mathrm{O} \mathrm{O}_{2} / 1$ ). A slight improvement in wastewater quality was achieved during the first few days after the addition the mixed culture of bacteria to the gravel filter. From day 6, the gradual increase in the percentages of removal in the examined parameters was observed reaching the maximum values at day 36 for the effluents of the three 
Table 1: Characteristics of the selected strains used as septic tank additives.

\begin{tabular}{|c|c|c|c|c|c|}
\hline Character & $\begin{array}{l}\text { Bacillus amylo- } \\
\text { liquefaciens }\end{array}$ & $\begin{array}{c}\text { Bacills } \\
\text { licheniformis }\end{array}$ & $\begin{array}{l}\text { Bacillus } \\
\text { subtilis }\end{array}$ & $\begin{array}{c}\text { Bacillus } \\
\text { megaterium }\end{array}$ & $\begin{array}{l}\text { Bacillus } \\
\text { pumilus }\end{array}$ \\
\hline Growth & Facultative & Facultative & Aerobic & Aerobic & Aerobic \\
\hline pH range & $6-10$ & $5-10$ & $4-10$ & $5-10$ & $6-10$ \\
\hline Temperature & $10-50$ & $10-55$ & $10-50$ & $4-45$ & $10-50$ \\
\hline $\begin{array}{c}\text { Production of: } \\
\text { Protease } \\
\text { (break down of } \\
\text { proteins) }\end{array}$ & t+ & t+ & t+t+ & t+t & t+t \\
\hline $\begin{array}{c}\text { Amylase } \\
\text { (break down of } \\
\text { carbohydrates) }\end{array}$ & t+ & t+ & t+t+ & + & + \\
\hline $\begin{array}{c}\text { Lipase } \\
\text { (break down of } \\
\text { grease) }\end{array}$ & t+ & t+ & $t+t+$ & t+t & t+t \\
\hline $\begin{array}{c}\text { Esterase } \\
\text { (break down of fats) }\end{array}$ & t+ & t+ & t+tt & $t+t$ & t+t \\
\hline $\begin{array}{c}\text { Cellulase } \\
\text { (break down of } \\
\text { cellulose) }\end{array}$ & t+ & + & $t+t+$ & $t+t$ & $t+t+$ \\
\hline $\begin{array}{c}\text { Xylanase } \\
\text { (break down of plant } \\
\text { materials) }\end{array}$ & t+ & + & t+t+ & $t+t$ & t+t+ \\
\hline $\begin{array}{c}\text { Urease } \\
\text { (break down of urea) }\end{array}$ & t+t & t+ & t+ & $t+t+$ & ++ \\
\hline
\end{tabular}

+ Moderate $++=$ Good $+++=$ Very Good $++++=$ Excellent.

septic tanks. The maximum percentage of removal achieved was ranged as: 91.3-94.4 for COD, 93-95.8 for BOD, 90-91.7 for TSS, 75-87 for oil and grease, and 99.95-99.99 for total coliform. After 42 days a gradual decrease in percentages of removal for all determined parameters was observed, but still higher than the values achieved in the absence of bacterial additives.

At the end of the experimental period (60 days) the effluent of the septic tanks had the following character: $\mathrm{COD} ; 77.2-104.8 \mathrm{mg} \mathrm{O}_{2} / 1$, BOD; 44.1-58.7 $\mathrm{mg} \mathrm{O}_{2} / 1$; TSS; 52.9-70.6 mg/l, Oil and Grease; 4.1-15 mg / and total coliform $10^{4}-10^{6}$ MPN/100 ml (Tables 2-4).

It is important to mention that septic tanks without bacterial additives showed removal percentages ranged as 79.3-88.5 for COD, 80-85.5 for BOD, 75.1-83 for TSS, oil and grease 28-41.7 for oil and grease, and 98.5-99.85 for total coliform (Tables 2-4). 
Table 2: Changes in parameters rested after the addition of bacterial additives to septic tank at El Mahamid Village, Aswan Governorate.

\begin{tabular}{|c|c|c|c|c|c|c|c|c|c|c|c|c|}
\hline \multirow{2}{*}{ parameters } & \multicolumn{12}{|c|}{ Time in days after bacterial addition } \\
\hline & 0 & 3 & 8 & 12 & 18 & 24 & 30 & 36 & 42 & 48 & 54 & 60 \\
\hline COD inf. & 580 & 565 & 568 & 578 & 585 & 805 & 615 & 820 & 635 & 640 & 650 & 655 \\
\hline COD eff. & 116 & 113 & 98.3 & 87.8 & 76.6 & 70.2 & 80.8 & 54 & 82.2 & 71 & 81 & 104.8 \\
\hline $\begin{array}{c}\% \\
\text { Removal }\end{array}$ & 79.3 & 80.3 & 82.7 & 84.8 & 86.8 & 88.4 & 80.1 & 81.3 & 90.2 & 88.8 & 88.0 & 84.1 \\
\hline BOD inf. & 400 & 405 & 418 & 428 & 435 & 450 & 470 & 465 & 440 & 435 & 430 & 425 \\
\hline BOD eff. & 80 & 87.1 & 72.3 & 84.2 & 54.4 & 45.5 & 37.1 & 32.6 & 35.6 & 41.8 & 51.2 & 58.7 \\
\hline $\begin{array}{c}\% \\
\text { Removal }\end{array}$ & 80 & 81.2 & 82.7 & 85 & 87.5 & 89.8 & 82.1 & 83.0 & 81.8 & 80.4 & 88.1 & 86.2 \\
\hline Tss inf. & 654 & 348 & 355 & 350 & 385 & 375 & 388 & 393 & 375 & 370 & 365 & 360 \\
\hline Tss eff. & 88 & 85.6 & 78.8 & 65 & 58.4 & 50.3 & 42.3 & 39.3 & 41.3 & 44.8 & 49.6 & 52.8 \\
\hline \%Removal & 75 & 75.4 & 77.8 & 81.4 & 84 & 86.6 & 89.1 & 80.0 & 89.0 & 87.8 & 84.4 & 85.3 \\
\hline $\begin{array}{c}\text { Oil \& } \\
\text { grease inf. }\end{array}$ & 64 & 63 & 65 & 70 & 71 & 73 & 75 & 70 & 78 & 65 & 63 & 80 \\
\hline $\begin{array}{c}\text { Oil \& } \\
\text { grease eff. }\end{array}$ & 46 & 42.8 & 35.7 & 30.8 & 22.7 & 15.3 & 11.3 & 9.1 & 10.8 & 12.4 & 12.2 & 15 \\
\hline \%Removal & 28 & 32 & 45 & 56 & 68 & 78 & 85 & 87 & 84 & 81 & 78 & 75 \\
\hline
\end{tabular}

Table 3: Changes in parameters rested after the addition of bacterial additives to septic tank at Benisand Village, Asuit Governorate.

\begin{tabular}{|c|c|c|c|c|c|c|c|c|c|c|c|c|}
\hline \multirow{2}{*}{ parameters } & \multicolumn{12}{|c|}{ Time in days after bacterial addition } \\
\hline & 0 & 3 & 6 & 12 & 18 & 24 & 30 & 36 & 42 & 48 & 54 & 60 \\
\hline CODinf. & 800 & 810 & 625 & 635 & 860 & 690 & 700 & 710 & 735 & 715 & 710 & 720 \\
\hline COD eff. & 87 & 86 & 1.3 & 73 & 84 & 66.6 & 50.4 & 47.6 & 52.2 & 80.8 & 85.3 & 78.2 \\
\hline $\begin{array}{c}\% \\
\text { Removal }\end{array}$ & 85.5 & 85.8 & 87 & 88.5 & 90.3 & 91.8 & 82.8 & 83.3 & 92.8 & 81.5 & 90.8 & 89.0 \\
\hline BODinf. & 350 & 353 & 358 & 360 & 365 & 368 & 375 & 388 & 390 & 85 & 383 & 380 \\
\hline BOD eff. & 58,7 & 54 & 48.4 & 42.8 & 36.8 & 29.1 & 24 & 22 & 27.3 & 33.5 & 38.3 & 44.1 \\
\hline $\begin{array}{c}\% \\
\text { Removal } \\
\end{array}$ & 84.1 & 84.7 & 86.2 & 88.1 & 89.8 & 82.1 & 83.6 & 84.3 & 83.0 & 91.3 & 90.0 & 88.4 \\
\hline Tss inf. & 434 & 440 & 450 & 455 & 450 & 485 & 473 & 470 & 465 & 475 & 480 & 478 \\
\hline Tss eff. & 73.8 & 73 & 68.3 & 63.7 & 56.8 & 50.7 & 44 & 38 & 41.1 & 47.5 & 52.3 & 86 \\
\hline \%Removal & 83 & 83.4 & 84.8 & 86.0 & 87.6 & 89.1 & 80.7 & 81.7 & 81.1 & 90.0 & 89.1 & 88.2 \\
\hline $\begin{array}{c}\text { Oil \& } \\
\text { grease inf. }\end{array}$ & 12.0 & 12.5 & 12.8 & 12.5 & 13.0 & 13.2 & 13.8 & 14.0 & 12.8 & 13 & 12.8 & 12.5 \\
\hline $\begin{array}{c}\text { Oil \& } \\
\text { grease eff }\end{array}$ & 8 & 8.1 & 7.54 & 6.34 & 5.5 & 4.5 & 3.6 & 3.5 & 3.47 & 3.73 & 3.84 & 4.1 \\
\hline \%Removal & 33.3 & 35.0 & 41.1 & 49.3 & 57.6 & 68.0 & 74.2 & 75.0 & 73.1 & 71.3 & 70.0 & 67.6 \\
\hline
\end{tabular}

All parameters were determined as $\mathrm{mg} / \mathrm{l}$. 
Table 4: Changes in parameters rested after the addition of bacterial additives to septic tank at Garagoos Village, Quina Governorate.

\begin{tabular}{|c|c|c|c|c|c|c|c|c|c|c|c|c|}
\hline \multirow{2}{*}{ parameters } & \multicolumn{12}{|c|}{ Time in days after bacteria addition } \\
\hline & 0 & 3 & 8 & 12 & 18 & 24 & 30 & 36 & 42 & 48 & 54 & 80 \\
\hline CODir & 840 & 835 & 855 & 870 & 878 & 680 & 710 & 715 & 720 & 705 & 712 & 720 \\
\hline COD eff. & 96 & 80.8 & 81.8 & 72.4 & 62.4 & 53 & 48.2 & 40 & 48 & 55.7 & 69.8 & 85.4 \\
\hline \% Removal & 85 & 85.7 & 87.5 & 88.2 & 90.8 & 92.3 & 83.5 & 84.4 & 83.2 & 82.1 & 90.2 & 88 \\
\hline BOD inf. & 400 & 408 & 418 & 435 & 450 & 468 & 477 & 489 & 494 & 480 & 480 & 482 \\
\hline BOD eff. & 58 & 57.5 & 53.5 & 47.8 & 41.8 & 35.1 & 27.2 & 20.5 & 24.7 & 32.8 & 41.8 & 54 \\
\hline \% Removal & 85.5 & 85.8 & 87.2 & 88 & 80.7 & 82.5 & 94.3 & 85.8 & 85.0 & 83.3 & 81.3 & 81.3 \\
\hline Tss inf. & 380 & 388 & 395 & 398 & 415 & 420 & 428 & 435 & 430 & 428 & 420 & 415 \\
\hline Tss eff. & 68.2 & 68.7 & 64.8 & 50.7 & 56.8 & 51.7 & 48.6 & 42.8 & 48.2 & 52.8 & 58.2 & 70.6 \\
\hline \%Removal & 81.8 & 82.3 & 83.8 & 85 & 88.3 & 87.7 & 88.1 & 80.2 & 88.8 & 87.7 & 85.8 & 93 \\
\hline $\begin{array}{c}\text { Oil \& } \\
\text { grease inf. }\end{array}$ & 12 & 11.8 & 12.5 & 12.8 & 13.3 & 13.7 & 13.8 & 14.2 & 14 & 12.8 & 13.2 & 13.0 \\
\hline $\begin{array}{c}\text { Oil \& } \\
\text { grease eff. }\end{array}$ & 7 & 6.7 & 8.5 & 5.8 & 5.2 & 4.5 & 3.6 & 2.94 & 3.3 & 3.4 & 4 & 4.3 \\
\hline \%removal & 41.7 & 43.2 & 48 & 54.5 & 60.8 & 67.5 & 74.3 & 79.3 & 78.5 & 73.8 & 89.8 & 87.1 \\
\hline
\end{tabular}

Other three septic tanks were selected in three villages, namely Enibis; Souhag governorate, Bani Sanad; Asuot governorate, and El-Mahameid; Aswan governorate to represent tanks receiving influent with high load of pollutants (COD; 1072-2180 $\mathrm{mg} \mathrm{O}_{2} / \mathrm{l}$ and BOD; 714-1200 $\mathrm{mg} \mathrm{O}_{2} / \mathrm{l}$, TSS 205-1144 mg/l, oil and grease 40-104 mg/l al total coliform $10^{8}-10^{9} \mathrm{MPN} / 100 \mathrm{ml}$. Again the actual improvement in the effluent quality appeared at the $6^{\text {th }}$ day after bacterial addition to the tanks. Microorganisms used for wastewater treatment are likely to be exposed to a wide variety of environmental stresses. Microorganisms must adapt to these conditions to be able to degrade the pollutants. In some cases genetic engineering may be helpful in augmenting resistance to such stress, thereby facilitating good performance of degradative organism under adverse conditions (Clark [15]).

In the present study, the maximum removal efficiency appeared after 42 days and may extend to 48 days. During this period, the removal percentages for COD, BOD, TSS, oil and grease and total coliform were ranged as 93.8-97.2, 94.5-97.0, 94.0-97.9; 64.0-93.8, 99.81-99.99, respectively (Tables 5-7).

Septic tanks without bacterial additives showed removal efficiency (as \%) ranged as 64.7-87.2, 73.4-89.6, 56.7-86.9, 34.6-45, and 92.8-99.28 for COD, BOD, TSS, oil and grease and total coliform, respectively. 
Table 5: Changes in parameters rested after the addition of bacterial additives to septic tank at El Mahamid Village, Aswan Governorate.

\begin{tabular}{|c|c|c|c|c|c|c|c|c|c|c|c|c|}
\hline \multirow{2}{*}{ parameters } & \multicolumn{10}{|c|}{ Time in days after bacteria addition } \\
\cline { 2 - 14 } & 0 & 3 & 6 & 12 & 18 & 24 & 30 & 36 & 42 & 48 & 54 & 60 \\
\hline COD inf. & 2180 & 2210 & 2230 & 2260 & 2290 & 2280 & 2310 & 2340 & 2380 & 2350 & 2280 & 2220 \\
\hline COD eff. & 280 & 2785 & 245.5 & 214.7 & 176.3 & 139.1 & 101.6 & 74.9 & 66.6 & 82.3 & 114 & 162.1 \\
\hline \% removal & 87.2 & 87.4 & 89.0 & 90.5 & 92.3 & 93.9 & 95.6 & 96.8 & 97.2 & 96.5 & 95.0 & 92.7 \\
\hline BOD inf. & 1200 & 1190 & 1230 & 1250 & 1280 & 1290 & 1295 & 1310 & 1330 & 1360 & 1290 & 1300 \\
\hline BOD eff. & 125 & 120.2 & 114.4 & 100 & 88.3 & 72.2 & 58.3 & 45.9 & 39.9 & 55.8 & 77.4 & 102.7 \\
\hline \% removal & 89.6 & 89.9 & 90.7 & 92.0 & 93.1 & 94.4 & 95.5 & 96.5 & 97.0 & 95.9 & 94.0 & 92.1 \\
\hline Tss inf & 1144 & 1160 & 1180 & 1210 & 1225 & 1250 & 1270 & 1290 & 1310 & 1325 & 1320 & 1310 \\
\hline Tss eff. & 150 & 148.5 & 139.2 & 127 & 111.5 & 98.8 & 81.3 & 67.1 & 61.6 & 79.5 & 100.3 & 115.3 \\
\hline \%removal & 86.9 & 87.2 & 88.2 & 89.5 & 90.9 & 92.1 & 93.6 & 94.8 & 95.3 & 94.0 & 92.4 & 91.2 \\
\hline $\begin{array}{c}\text { Oil \& } \\
\text { grease inf. }\end{array}$ & 104 & 106 & 109 & 112 & 115 & 120 & 123 & 108 & 118 & 120 & 117 & 115 \\
\hline $\begin{array}{c}\text { Oil \& } \\
\text { grease eff. }\end{array}$ & 68 & 67.8 & 65.7 & 61.9 & 58.4 & 55 & 48.8 & 37.4 & 40.5 & 43.2 & 44.7 & 46 \\
\hline \%oremoval & 34.6 & 36 & 39.7 & 44.7 & 49.2 & 54.2 & 60.3 & 65.4 & 65.7 & 64 & 61.8 & 60 \\
\hline
\end{tabular}

Table 6: Changes in parameters rested after the addition of bacterial additives to septic tank at Anebas Village, Sohag Governorate.

\begin{tabular}{|c|c|c|c|c|c|c|c|c|c|c|c|c|}
\hline parameters & \multicolumn{10}{|c|}{ Time in days after bacteria addition } \\
\cline { 2 - 16 } & 0 & 3 & 6 & 12 & 18 & 24 & 30 & 36 & 42 & 48 & 54 & 60 \\
\hline COD inf. & 1072 & 1082 & 1120 & 1070 & 1090 & 1115 & 1135 & 1100 & 1150 & 1125 & 1110 & 1100 \\
\hline COD eff. & 234 & 233.7 & 224 & 181.9 & 157 & 127.1 & 96.5 & 62.7 & 51.8 & 58.5 & 81 & 99 \\
\hline \% removal & 78.2 & 78.4 & 80 & 83 & 85.6 & 88.6 & 91.5 & 94.3 & 95.5 & 94.8 & 92.7 & 91.0 \\
\hline BOD inf. & 714 & 720 & 730 & 755 & 770 & 790 & 805 & 820 & 810 & 825 & 800 & 790 \\
\hline BOD eff. & 142.1 & 140.4 & 126.3 & 111.7 & 93.2 & 75.8 & 55.5 & 36.1 & 34 & 41.3 & 52.8 & 53.7 \\
\hline \%Removal & 80.1 & 80.5 & 82.7 & 85.2 & 87.9 & 90.4 & 93.1 & 95.6 & 95.8 & 95.0 & 93.4 & 92.2 \\
\hline Tss inf & 852 & 850 & 870 & 887 & 900 & 920 & 938 & 960 & 985 & 970 & 930 & 900 \\
\hline Is5 eff. & 160 & 158.1 & 1479 & 131.3 & 112.5 & 93.8 & 72.2 & 56.6 & 50.2 & 58.2 & 67 & 82.8 \\
\hline \%Removal & 81.2 & 81.4 & 83 & 85.2 & 87.5 & 89.8 & 92.3 & 94.1 & 94.9 & 94.0 & 92.8 & 90.8 \\
\hline $\begin{array}{c}\text { Oil \& } \\
\text { grease inf. }\end{array}$ & 40 & 40.1 & 40.3 & 40.8 & 41.0 & 41.7 & 42.3 & 43 & 72.7 & 42 & 41.8 & 41.0 \\
\hline $\begin{array}{c}\text { Oil \& } \\
\text { grease eff. }\end{array}$ & 22 & 21.5 & 20.2 & 17.95 & 15.79 & 13.43 & 11 & 8.6 & 8.33 & 8.44 & 9.4 & 10.25 \\
\hline \%Removal & 45 & 46.5 & 50 & 56 & 61.5 & 67.8 & 74 & 80 & 80.5 & 79.9 & 77.5 & 75 \\
\hline
\end{tabular}

\section{Conclusions}

Although, the removal efficiency of septic tanks with bacterial additives was higher in case of those receiving the high load of pollutants in the influent than in those receiving medium load, the pollutants residual in the final effluent (after 60 days) of the first case are higher (Tables 2-7). The further decrease in the total coliform density resulted after using bacterial additives may be due to the possibility of antimicrobial agent production. For example, B. licheniformis is capable of producing several antimicrobial agents such as licheniformin [16], bacitracin [17] and others. In addition, metabolite(s) produced by $B$. licheniformis and B. amyloliquefaciens showed antifungal activity [18-20]. 
Table 7: Changes in parameters rested after the addition of bacterial additives to septic tank at Benisand Village, Asuit Governorate.

\begin{tabular}{|c|c|c|c|c|c|c|c|c|c|c|c|c|}
\hline \multirow{2}{*}{ perameaters } & \multicolumn{12}{|c|}{ Time in days after bacteria addition } \\
\hline & 0 & 3 & 6 & 12 & 18 & 24 & 30 & 36 & 42 & 48 & 34 & 60 \\
\hline COD inf & 1360 & 1330 & 1410 & 1280 & 1330 & 1400 & $\begin{array}{c}139 \\
0\end{array}$ & 1360 & 1425 & $\begin{array}{c}137 \\
0\end{array}$ & 1350 & 1340 \\
\hline$C O D$ off. & 450 & 463 & 481 & 339 & 279.3 & 217 & 132 & 84 & 74 & 82.2 & 95.85 & 124.6 \\
\hline \% Removal & 64.7 & 65.2 & 68 & 73.5 & 79 & 84.5 & 90.5 & 93.8 & 94.8 & 94.0 & 92.9 & 90.7 \\
\hline BOD inf & $9 \mathrm{BO}$ & 950 & 1030 & 920 & 950 & 1000 & 990 & 1055 & 1020 & 980 & 980 & 960 \\
\hline$B O D$ off. & 260 & 247 & 226.6 & 165.6 & 147.3 & 120 & $\$ 4.2$ & 38 & 49 & 49 & 93.7 & 74.9 \\
\hline \% Removal & 73.4 & 74 & 78 & 82 & 84.5 & BS & 91.5 & 945 & 95.2 & 95 & 93.5 & 92.2 \\
\hline Tu ixf. & 2051 & 1980 & 2100 & 1880 & 1970 & 2050 & 2040 & 2000 & 2250 & 2150 & 2000 & 2000 \\
\hline Tus efE. & SSB & 817.74 & 798 & 573.4 & 457 & 329 & $\begin{array}{c}177 . \\
5\end{array}$ & 60 & 47.25 & 47.3 & 96 & 124 \\
\hline \%Removal & 56.7 & 58.7 & 62 & 69.5 & 76.8 & 84 & 91.3 & 97 & 97.9 & 97.8 & 95.2 & 93.8 \\
\hline $\begin{array}{c}\text { Oil \& } \\
\text { gease inf. }\end{array}$ & 3.4 & 3.3 & 3.8 & 3.1 & 3.9 & 3.5 & 3.7 & 3.2 & 3.9 & 3.6 & 3.6 & 3.4 \\
\hline $\begin{array}{c}\text { Oil \& } \\
\text { Eoase off. }\end{array}$ & 2 & 1.8 & 1.92 & 1.3 & 1.29 & 0.84 & 0.56 & 0.2 & 0.22 & 0.22 & 0.27 & 0.28 \\
\hline \%Remevzl & 41.1 & 45.5 & 49.5 & 58.0 & 66.8 & 76.1 & 85.0 & 97.8 & 94.4 & 93.9 & 92.6 & 91.8 \\
\hline
\end{tabular}

From the results, it seemed that septic tanks need to be reinoculated with the selected strains after 30-45 days. Cells inoculated in the gravel filter start to reproduce firm biofilm on gravel surfaces as well as on the tank walls. The decrease in bacterial activities and pollutants removal efficiency may be due to one or more of the following reasons. The first is the presence of toxic materials in the wastewater which can inhibit the survival of the community. The second, is that such chemicals may produced and biochemically incompatible with the effective catabolism of the target compound and may poison the process. The third reason is the interactions between microorganisms such as the lytic activity of amoebicin m-4-A that produced by $B$. licheniformis against B. megaterium [21]. The forth possibility is that biofilm formed may slough out and lost by the time with the effluent. The use of other material than gravel which have rough surface may be much more helpful.

Concerning the use of cultured bacteria as additives to septic tanks in order to provide the system with types of bacteria at density necessary to improve and enhance system function, there are two approaches. The first say that because of the presence of significant numbers and types of bacteria, enzymes, yeasts, and fungi in typical residential and commercial wastewaters, the use of septic system additives containing these or any other ingredients is not recommended [10]. The second approach recommended the use of bacterial additives for septic tanks under normal as well as adverse conditions.

The use of selected and adapted natural bacteria as additive have the same advantage as the home field ones and the competition with the native bacteria of the system won't exist. These bacteria can reduce retained organic molecules to soluble compounds and gases. This digestion can significantly further reduce sludge volume especially in warm climate of the Upper Egypt. Material degraded by bacteria does not contribute in increasing the loading of BOD, TSS. 
Users must be aware that when the application of bacterial additives is not the solution for all symptoms of septic tank failures the cause of failure should be identified and appropriate corrective action taken to prevent recurrences.

Finally, in any case, bacterial additives are not an alternative to proper maintenance and do not eliminate the need for routine pumping for a septic tank.

\section{References}

[1] U.S.EPA., Design manual for onsite wastewater treatment and disposal systems. U.S.EPA 625/1-80-012, U.S.EPA, Washington, DC., 1980.

[2] Hoover, M.T., Disy. T. M., Pfeiffer, M.A., Dudley, N., Mayer, R.B., and Buffington, B., North Carolina Subsurface System Operators Training School Manual. Raleigh, N.C.: Soil Science Department, College of Agriculture and Life Sciences, North Carolina State University and North Carolina Department of Environment, Heath and Natural Resources, 1996.

[3] Montgomery, T., On-site wastewater treatment systems: A brief description of ecological economic and regulatory factors. The New Alchemy Institute Technical Bulletin No. 6, 1990.

[4] Seifer, R. Septic system fact sheets. Alaska Cooperative Extension, University of Alaska, Fairbanks, 1999.

[5] Jarrett. A. R., Fritton, D.D., and Sharpe, W.E., Renovation of failing absorption fields by water conservation and resting. American Asssociation of Agricutural Engineers Paper 85-2630, 1985.

[6] Gannon, R.W., Bartenhagen, K.A., and Hargrove, L.L, Septic Systems: Best management practice. North Carolina State University, Water Quality Group, 1999.

[7] Brown, R.B., Soils and septic systems. Fact sheet SL-118 University of Florida Cooperative Extension Service, 1998.

[8] U.S. EPA., Decentralized systems technology fact sheet, septic tank - soil absorption systems. United State Environmental Protection Agency, EPA 932-F-99-075, Office of Water, Washington, D.C., 1999.

[9] American Public Health Association (APHA), Standard Methods for the Examination of Water and Wastewater APHA, 20 ${ }^{\text {th }}$ Edit., Washington, D.C., 1998.

[10] U.S.EPA, Onsite wastewater treatment systems, special issues Fact sheet 1septic tank additives. U.S Environmental Protection Agency, National Risk Management Research Laboratory. EPA 625/R-00/008, 2005.

[11] Banerjee, C., Bustamante, C.I., Wharton, R., Tally, E., and Wade, J.C., Bacillus infections in patients with cancer. Arch. Intern. Med. 148: 17691774, 1988.

[12] Edberg, S.C., USEPA human herlth assessment: Balillus licheniformis. Upublished U.S. Environmental Protection Agency, Washinton, D.C, 1992.

[13] Claus, D. and Berkeley, R.C.W., Genus Baillus chon 1872, pp. 1105-1139. In: P.H.A. Sneath, et al. (eds.) Bergey's Manual of Systematic Bacteriology, vol. 2. Williams and Wilkins Co., Baltimore, MD, 1986. 
[14] Norris, J.R., Berkeley, R.C.W., Logan, N.A., and O’Donnell, A. G., The genera Bacillus and sporolactobaillus. In: M.P. Starr et al. (eds.), The prokaryotes: A Handbook on Habitats, Isolation and Identification of Bacteria, Vol. 2. Springer-Verlag, Berlin, pp. 1711-1742, 1981.

[15] Clark, G.H., The effect of bacterial additives on septic tank performance. Master's Thesis, North Carolina state University, Department of Soil Science, Raleigh, NC., 1999.

[16] Callow, R.K., and Hart, P.D., Antibiotic material from Bacillus licheniformis (weigmann, emend Gibson) active against species of mycobacteria.. Nature $15: 334,1946$.

[17] Johnson, B.A., Anker, H, and Meleney, F.L. Bacitracin: A new antibiotic produced by a member of the B. subtilis group. Sci. $102: 376-377,1945$.

[18] Shigemitsu, H., Hirano, K., Kohno, M., Eshizaki H., and Kunoh, H., Effect of Bacillus licheniformis on Fusarium oxysporum f. sp. Cucumerinum. Trans. Mycological Society of Japan 24: 477-486, 1983.

[19] Scharen, A.L., and Bryan, M.D. A possible biological control agent for net blotch of barely. Phytopathol. 71 : 902-903, 1981.

[20] Yoshida, S., Hiradate, S., Tsukamoto, T., Hatakeda, K., and Shirata, A., Antimicrobial activity of culture filtrate of Bacillus amyloliquefaciens RC2 isolated from mulberry leaves. Phytopathology 91: $181-187,2001$.

[21] Lebbadi, M., Galvez, A., Valdivia, E., Martinez-Buen, M., and Maqueda, M., Biological activity of amoebicin m-4 from B. licheniformis M-4. Antimicrobial Agents Chemother 38, 1820 - 1823, 1994 . 